\title{
KEEFEKTIFAN MODEL PEMBELAJARAN THINK TALK WRITE BERBANTU MEDIA PUZZLE TERHADAP HASIL BELAJAR SISWA KELAS V MATA PELAJARAN IPS SD NEGERI KUTOSARI 02 BATANG
}

\author{
Rudi Hidayat ${ }^{1}{ }^{*}$, Choirul Huda $^{2}$, Qoriati Mushafanah ${ }^{3}$ \\ 1 Universitas PGRI Semarang, Indonesia \\ 2 Universitas PGRI Semarang, Indonesia \\ 3 Universitas PGRI Semarang, Indonesia
}

\begin{abstract}
Abstrak
Penelitian ini dilatar belakangi oleh rendahnya hasil belajar siswa kelas $\mathrm{V}$ mata pelajaran IPS. Hal tersebut dikarenakan kurangnya inovasi model dan media pembelajaran dalam kegiatan belajar mengajar di kelas. Permasalahan dalam penelitian ini adalah Apakah Model Pembelajaran Think Talk Write berbantu media Puzzle dapat membantu meningkatkan hasil belajar siswa kelas V mata pelajaran IPS SD Negeri Kutosari 02 Batang? Dengan tujuan yang hendak dicapai dalam penelitian ini untuk mengetahui keefektifan model pembelajaran Think Talk Write berbantu media Puzzle terhadap Hail Belajar siswa kelas V mata pelajaran IPS SD Negeri Kutosari 02 Batang. Desain penelitian Pretest-Posttest Control Group Design. Populasi penelitian adalah seluruh siswa kelas V SD Negeri Kutosari 02 Batang dengan sampel penelitian yaitu kelas VA dan VB. Data dalam penelitian ini diperoleh melalui tes, observasi, dokumentasi, dan wawancara. Teknik analisis data yang digunkan yaitu uji prasyarat data dan uji hipotesis. Berdasarkan uji-t diperoleh thitung sebesar 2,76285 sedangkan ttabel dengan $\mathrm{dk}=\mathrm{n} 1+\mathrm{n} 2-2=22+23-2=43$, dan taraf signifikan 0,05 maka diperoleh ttabel sebesar 1,68. Karena thitung > ttabel yaitu 2,76285 > 1,68 maka H0 ditolak dan Ha diterima. Maka dapat disimpulkan bahwa model pembelajaran Think Talk Wrtite berbantu media puzzle lebih efektif dalam meningkatkan hasil belajar siswa kelas V mata pelajaran IPS SD Negeri Kutosari 02 Batang dibanding dengan menggunakan model konvensional. Saran yang dapat penulis sampaikan pada penelitian ini adalah agar model pembelajaran Think talk Write dapat digunakan sebagai alternatif model pembelajaran dalam kegiatan pembelajaran.
\end{abstract}

\author{
Keywords: \\ Think Talk Write, \\ Media Puzzle, \\ Hasil Belajar
}

\section{Pendahuluan}

Undang-Undang Republik Indonesia No. 20 tahun 2003 tentang sisdiknas pada pasal 1 menyebutkan disebutkan bahwa pendidikan adalah salah satu usaha sadar dan terencana untuk mewujudkan suasana belajar dan proses pembelajaran siswa secara aktif mengembangkan potensi dirinya untuk memiliki kekuatan spiritual, keagamaan, pengendalian diri, kepribadian, kecerdasan, akhlak mulia, serta keterampilan yang diperlukan dirinya, masyarakat, bangsa, dan negara. Pendidikan memegang peranan yang sangat penting di berbagai sektor kehidupan. Pendidikan yang berkualitas akan menciptakan sumber daya manusia yang berkualitas pula (Juniasih, 2013). Untuk dapat membentuk peradaban bangsa yang bermartabat maka pendidikan harus menjadi prioritas pertama dan utama. Sukses atau tidaknya suatu pendidikan tergantung pada semua komponen yang terlibat dalam suatu pendidikan (Lestari, 2016). Tujuan pendidikan tersebut akan tercapai apabila guru mampu menciptakan suatu proses pembelajaran yang optimal sehingga siswa mencapai hasil belajar sesuai KKM (Kriteria Ketuntasan Minimal) atau bahkan lebih. Pembelajaran yang aktif selalu diiringi dengan aktivitas yang aktif serta adanya kemampuan cara berpikir siswa yang kritis terhadap materi yang dibelajarkan oleh guru ( Gunawan, 2016).

Permasalahan dilapangan yang terjadi pada kelas V SD Negeri Kutosari 02 Batang diantaranya penggunaan model pembelajaran ceramah dalam kegiatan pembelajaran dan siswa kurang aktif selama 
pembelajaran berlangsung, hal tersebut tidak sesuai dengan tujuan pendidikan yang termuat dalam UU no. 20 Th. 2003 pasal 1, yang mengakibatkan hasil belajar siswa tidak sesuai harapan atau tuntas KKM khususnya pada mata pelajaran IPS. Pada dasarnya pendidikan IPS berhubungan erat dengan pengetahuan, keterampilan, sikap, dan nilai-nilai dalam rangka berpartisipasi di dalam masyarakat, negara, dan bahkan didunia (Banks dalam Susanto, 2013: 141). Karakterisitik mata pelajaran IPS menurut wali kelas VA SD Negeri Kutosari 02 Batang, IPS merupkan mata pelajaran yang menuntut siswa untuk menghafal (hafalan) dikarenakan materi dari IPS tersebut bersifat abstrak sehingga siswa seusia kelas V SD yang tahapan berpikirnya masih dalam tahapan berpikir secara konkret terkadang mengalami kesulitan dalam memahami materi-materi IPS tersebut.

Penggunaan model pembelajaran yang tepat dapat mendorong tumbuhnya rasa senang siswa terhadap pelajaran, menumbuhkan dan meningkatkan motivasi dalam mengerjakan tugas, memberikan kemudahan bagi siswa untuk memahami pelajaran sehingga memungkinkan siswa mencapai hasil belajar yang lebih baik (Aunurrahman 2009: 143).

Berdasakan permasalahan tersebut peneliti menerapkan model pembelajaran Think Talk Write. Model pembelajaran Think Talk Write merupakan model pembelajaran berkelompok yang terdiri dari tiga fase, yaitu fase think (berpikir), fase talk (berbicara) dan fase write (menulis). Think Talk Write pada dasarnya dibangun melalui berpikir, berbicara, dan menulis. Alur kemajuan strategi Think Talk Write dimulai dari keterlibatan siswa dalam berpikir atau berdialog dengan dirinya sendiri setelah proses membaca. Selanjutnya berbicara dan membagi ide (sharing) dengan temannya sebelum menulis (Hamdayama, 2014: 217). Sedangkan menurut Chandra (2014), TTW dimulai dari keterlibatan siswa dalam berfikir sendiri setelah membaca materi selanjutnya berbicara atau membagikan ide dengan teman dan dilanjutkan dengan menuliskan laporan atau kesimpulan. Menurut Sugiantari (2016) pelaksanaan pembelajaran dengan model Think Talk Write (TTW) akan lebih maksimal jika didukung oleh media pembelajaran yang tepat. Oleh karena itu model pembelajaran tersebut divariasikan dengan media puzzle sebagai alat bantu untuk mengoptimalkan proses pembelajaran dengan cara bermain dan berdiskusi. Dari penerapan model Think Talk Write yang divariasikan dengan media puzzle diharapkan dapat meningkatkan hasil belajar siswa.

Rumusan Masalah dalam penelitian ini adalah "Apakah model pembelajaran Think talk Write berbantu media puzzle efektif meningkatkan hasil belajar siswa kelas V pata pelajaran IPS SD Negeri Kutosari 02 Batang?".

Tujuan dari penelitian tersebut dalah untuk mengetahui keefektifan model Think Talk Write terhadap hasil belajar siswa kelas V mata pelajaran IPS SD Negeri Kutosari 02 Batang.

Menurut Supriyono (2014: 5) berpendapat bahwa "Hasil belajar adalah pola-pola perbuatan, nilai-nilai, pengertian-pengertian, sikap-sikap, apersepsi dan keterampilan". Dalam Susanto (2013: 5) hasil belajar adalah perubahan-perubahan yang terjadi pada diri siswa, baik menyangkut aspek kognitif, afektif, dan psikomotorik sebagai hasil dari kegiatan belajar. Pengertian tersebut dipertegas oleh Nawawi (dalam Susanto, 2013: 7) yang menyatakan bahwa hasil belajar dapat diartikan sebagai tingkat keberhasilan siswa dalam mempelajarai meteri pelajaran disekolah yang dinyatakan dalam skor yang diperoleh dari hasil tes mengenal sejumlah materi pelajaran tertentu.

Media (Sadiman, dkk, 2012: 7) adalah segala sesuatu yang dapat digunakan untuk menyalurkan pesan dari pengirim ke penerima sehingga dapat merangsang pikiran, perasaan, perhatian dan minat serta perhatian siswa sedemikian rupa sehingga proses belajar terjadi. Dalam pendidikan, media difungsikan sebagain sarana untuk mencapai tujuan pembelajaran. Karenanya informasi yang terdapat dalam media harus dapat melibatkan siswa, baik dalam benak maupun mental dalam bentuk aktifitas yang nyata, sehingga pembelajaran dapat terjadi (Kustandi, dkk 2011: 23).

Peneliti memilih model pembelajaran Think Talk Write yang divariasikan dengan media puzzle berupa puzzle tokoh kemerdekaan yang terdiri dari dua sisi, sengan sisi luar berupa gambar tokoh kemerdekaa dan sisi dalam berisi potongan informasi tetntang tokoh tersebut, dan nantinya siswa diminta mencari informasi dari puzzle tersebut dan menyatukan kembali. Dan pada bagian akhirnya setiap kelompok melakukan presentasi didepan kelas. Setelah dipresentasikan setiap kelompok membuat pertanyaan beserta jawabannya kemudian pertanyaan tersebut ditukar kepada kelompok lain untuk dijawab, apabila siswa atau kelompok menjawab benar maka memperoleh nilai atau point.

Penelitian tentang penggunaan model pembelajran Think Talk Write yang telah dilakukan oleh Komang Ratna Puspa Sari dengan judul penelitian " Pengaruh Strategi Pembelajaran Think Talk Write (TTW) terhadap Hasil Belajar Ilmu Pengetahuan Alam Siswa Kelas IV SD N 1 Peguyangan Denpasar" dari hasil uji hipotesis dengan uji t, dengan menggunakan taraf signifikan 5\% dengan derajat kebebasan 78 diperoleh ttabel sebesar 2,000 sedangkan thitung berdasarkan hasil analisis diperoleh 8,05 sehingga thitung > tabel makadapat disipulkan bahwa $\mathrm{H}_{0}$ ditolak dan $\mathrm{H}_{a}$ diterima dan dinyatakan bahwa terdapat perbedaan yang signifikan antara siswa yang dibelajarkan melalui model pembelajaran kooperatif tipe Think Talk 
Write (TTW dengan siswa yang dibelajarkan melalui pembelajaran konvensional. Didasari permasalahan dilapangan dan dengan rujukan dari penelitian sebelumnya, maka diadakan penelitian dengan judul “ Keefektifan model pembelajaran Think Talk Write berbantu media Puzzle terhadap hasil belajar siswa kelas V mata pelajaran IPS SD Negeri Kutosari 02 Batang".

\section{Metode Penelitian}

Penelitian ini dilakukan di SD Negeri Kutosari 02 Jl. Raya Kutosari Desa Kutosari, Kecamat Gringsisng, Kabupaten Batang. Penelitian disasarkan pada semester genap kelas V tahun ajaran 2016/2017, pada tanggal 8-10 mei 2017.

Dalam penelitian ini ada dua macam variabel yaitu variabel bebas dan variabel terikat. Variabel bebas dalam penelitian ini yaitu model pembelajaran Think Talk Write berbantu media puzzle, sedangkan variabel terikat dalam penelitian ini adalah hasil belajar siswa kelas V SD Negeri Kutosari 02 Batang. Sampel adalah bagian (anggota) dari popilasi yang diambil secara benar, karena dapat mewakili populasi secara sah (representatif) (Soegeng, 2016: 94). Sampel dalam penelitian ini adalah siswa kelas V SD Negeri Kutosari 02 Batang yaitu kelas VA dan VB. Teknik sampling yang digunakan dalam penelitian ini adalah teknik sampling cluster random sampling. Dimana kelas V pararel 2 kelas yaitu kelas VA dan VB, dan Kelas VA sebagai kelas eksperimen yang akan diberi perlakuan dengan model pembelajaran Think Talk Write sedangkan kelas VB merupakan kelas kontrol yang akan diberi perlakuan dengan model pembelajaran konvensional atau ceramah.

Penelitian ini merupakan penelitian eksperimen kuantitatif dengan desain penelitian Pretestposttest control group design. Yaitu dengan menggunakan dua subjek penelitan yaitu kelas VA dan kelas VB. Penelitian ini dilakukan dengan membandingkan nilai pretest-posttes dan hasil belajar akhir (nilai posttest) dari kedua kelas tersebut. Dimaksudkan untuk mengetahui tingkat keefektifan dari model pembelajaran Think Talk Write yang diberikan pada kelas VA SD Negeri Kutosari 02 Batang.

Keefektifan (KBBI, 2008: 374) berasal darikata efektif yang mempunyai arti ada efeknya (akibatnya, pengaruhnya, kesannya), dapat membawa hasil, berhasil guna (tentang suatu usaha, tindakan). Sedangkan kata keefektifan mempunyai arti keadaan berpengaruh, keberhasilan (tentang usaha, tindakan). Keefektifan juga bisa diartikan sebagai suatu keberhasilan dari suatu usaha tertentu atau tindakan tertentu. Pembelajaran dianggap efektif apabila skor yang dicapai siswa memenuhi batas minimal kompetensi yang telah dirumuskan (Uno, 2015: 173).

Tahapan penelitian adalah sebagai berikut: (a) tahapan persiapan, yang meliputi: penentuan materi, membuat rancangan pembelajaran, menyesuaikan alokasi waktu, membuat kisi-kisi instrumen soal dan menyusun instrumen soal. (b) tahapan pelaksanaan, yaitu melakukan pembelajaran sesuai dengan rancangan penelitian pada kelas yang telah ditentukan. (c) tahapan analisis, meliputi: analisis awal, analisis akhir dan uji hipotesis.

Dalam penelitian ini penliti menggunakan instrumen tes berupa soal pilihan ganda yang sudah di uji validitas, reliabilitas, taraf kesukran, dan daya pembeda. Instrumen soal tersebut berjumlah 30 butir soal pada mata pelajaran IPS kompetensi dasar "Menghargai jasa dan peranan tokoh perjuangan dalam mempersiapkan kemerdekaan Indonesia". Selanjutnya nilai test yang diperoleh siswa (pretest dan posttest) di uji normalitas menggunakan uji lillieforse dan uji homogenitas menggunakan uji F. Pada analisis data akhir yang diperoleh dari nilai tes akhir siswa (posttest), kemudian di uji normalitas akhir dengan menggunakan uji lillieforse, uji ketuntasan belajar yang meliputi ketuntasan belajar individu dan klasikal, uji hipotesis menggunakan uji t-test, dan uji N-gain untuk mengetahui peningkatan hasil belajar siswa.

Hasil

\section{Hasil Dan Pembahasan}

Hasil penelitian yang dilakukan pada SD Negeri Kutosari 02 Batang diperoleh nilai awal siswa (pretest) untuk kelas eksperimen dan kelas kontrol adalah sebagai berikut 1.

Tabel 1

Rekapitulasi nilai pretest kelas eksperimen dan kelas control

\begin{tabular}{ccccccc}
\hline Kelas & $\begin{array}{c}\text { Jumlah } \\
\text { siswa }\end{array}$ & Rata-Rata & $\begin{array}{c}\text { Nilai } \\
\text { tertinggi }\end{array}$ & $\begin{array}{c}\text { Nilai } \\
\text { terendah }\end{array}$ & $\begin{array}{c}\text { Tuntas } \\
\text { (siswa) }\end{array}$ & $\begin{array}{c}\text { Tidak Tuntas } \\
\text { (siswa) }\end{array}$ \\
\hline Eksperimen & 22 & 59,95 & 80 & 43 & 7 & 15 \\
Kontrol & 23 & 53,35 & 80 & 33 & 6 & 17 \\
\hline
\end{tabular}


Grafik 1

Hasil penelitian nilai pretest

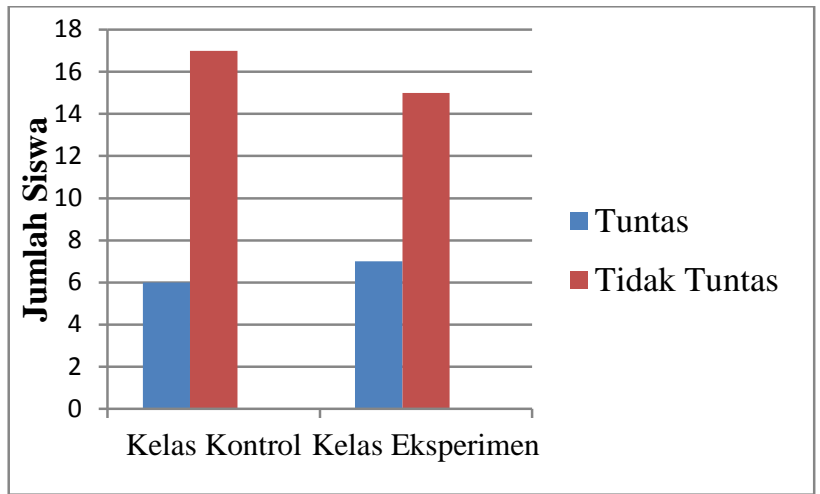

Dari tabel 1 dan grafik 1, dapat dilihat selisih hasil belajar siswa pada kelas eksperimen dan kelas kontrol. Nilai tersebut merupakan nilai siswa sebelum diberi perlakuan dengan model pembelajaran masing-masing. Setelah dilakukan tes awal (pretest) dan dipat hasilnya, kemudian dilakukan pembelajaran denga perlakuan masing-masing. Untuk kelas eksperimen diberi perlakuan dengan model pembelajaran Think Talk Write berbantu media puzzle, sedangkan untuk kelas kontrol diberi perlakuan dengan menggunakan model konvensional atau ceramah. Setelah diberi perlakuan kemudian dilakuakn tes akhir (posttest) dan didapat hasil posttest sebagai berikut:

Tabel 2

Rekapitulasi nilai posttest kelas ekperimen dan kelas control

\begin{tabular}{ccccccc}
\hline Kelas & $\begin{array}{c}\text { Jumlah } \\
\text { siswa }\end{array}$ & Rata-Rata & $\begin{array}{c}\text { Nilai } \\
\text { tertinggi }\end{array}$ & $\begin{array}{c}\text { Nilai } \\
\text { terendah }\end{array}$ & $\begin{array}{c}\text { Tuntas } \\
\text { (siswa) }\end{array}$ & $\begin{array}{c}\text { Tidak Tuntas } \\
\text { (siswa) }\end{array}$ \\
\hline Eksperimen & 22 & 80,32 & 93 & 67 & 19 & 3 \\
Kontrol & 23 & 70,35 & 90 & 43 & 12 & 11 \\
\hline
\end{tabular}

Grafik 2

Hasil penelitian nilai posttest

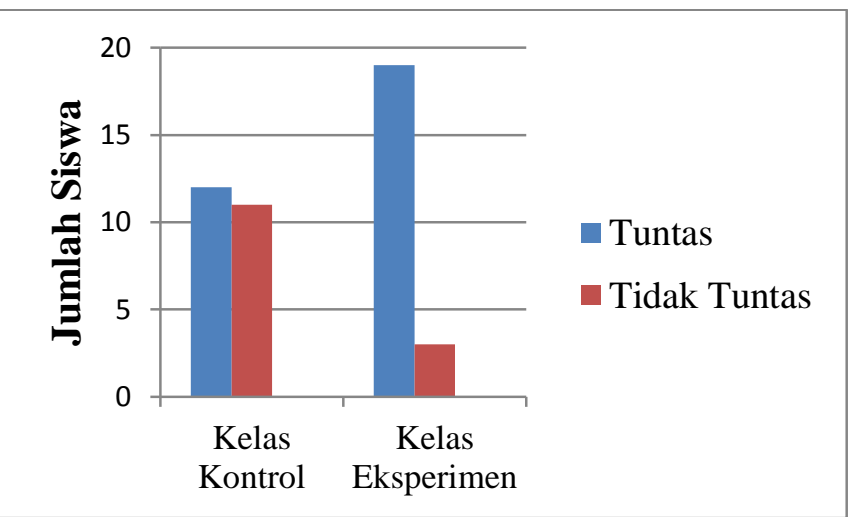

Data nilai hasil pretest dan posttest kemudian dilakuan pengujian normalitas dengan uji lillieforse. Pada hasil nilai pretest dilakuakan pengujian normalitas awal untuk masing-masing kelas. Untuk uji normalitas awal pada kelas eksperimen dipeoleh $\mathrm{L}_{0}=0,182$ dan $\mathrm{L}_{\text {tabel }}=0,190$ maka $\mathrm{L}_{0}>\mathrm{L}_{\text {tabel }}$ sehingga data berdistribusi normal, untuk kelas kontrol diperoleh $\mathrm{L}_{0}=0,130$ dan $\mathrm{L}_{\text {tabel }}=0,173$ maka $\mathrm{L}_{0}>$ Ltabel sehingga data berdistribusi normal.

Setelah didapat data dari kedua kelas berdistribusi normal, kemudian dilakukan uji homogenitas dengan uji $\mathrm{F}$, dengan $\mathrm{S}^{2}=296,0252$ dan $\mathrm{B}=106,267$ diperoleh hasil $\chi^{2}$ sebesar 3,7286 dengan taraf nyata sebesar $5 \%$ atau interval kepercayaan sebesar $95 \%$ dan $d k=1$ maka diperoleh $\chi^{2} 95 \%(1)=3,84$. Sehingga $\chi^{2}$ 
$<\chi^{2} 95 \%(1)$, karena chi hitung $(3,7286)<$ chi tabel $(3,84)$ maka dapat disimpulkan bahwa kedua kelompok mempunyai varian yang homogen.

Setelah dilakukan analisis pada hasil pretest siswa, kemudian hasil posttest dulakukan pengujian uji normalitas dengan uji lillieforse. Untuk kelas eksperimen diperoleh $\mathrm{L}_{0}=0,148$ dan Ltabel $=0.190$ maka $\mathrm{L}_{0}$ $>$ Ltabel sehingga data berdistribusi normal, untuk kelas komtrol diperoleh $\mathrm{L}_{0}=0,147$ dan $\mathrm{Ltabel}=0,173$ maka $\mathrm{L}_{0}>$ Ltabel sehingga data berdistribusi normal.

Untuk mengetahui ketuntasan belajar individu siswa :

ketuntasan individu $=\frac{\text { skor } y \text { ang diperoleh }}{\text { skor maksimal }} \times 100 \%$

siswa dapat dikatakan tuntas secara individu apabila hasil nilai siswa $\geq 75$, dari perhitungn ketuntasan individu siswa kelas eksperimen diperoleh 19 siswa tuntas dan 3 siswa tidak tuntas, sedangkat untuk kelas kontrol 12 siswa tuntas dan 11 siswa tidak tuntas.

Untuk mengetahui ketuntasan belajar secara klasikal siswa:

$$
\text { Tingkat ketuntasan }=\frac{\text { jumlah siswa y ang tuntas belajar }}{\text { jumlah siswa yang mengikuti tes }} \times 100 \%
$$

Ketuntasan belajar secara klasikal, dikatakan tuntas apabila sekurang-kurangnya 75\% dari siswa berhasil mencapai tingkat ketuntasan yang telah ditetapkan atau KKM.. dari hasil perhitungan, kelas ekperimen tuntas secara klasikal 86,6363\% dan kelas kontrol tuntas secara klasikal 52,1739\%.

Hipotesis penelitian dalam penelitian ini yang akan diuji adalah

$H_{0}=$ Model pembelajaran Think Talk Write berbantu media puzzle tidak efektif dalam meningkatkan hasil belajar siswa kelas $V$ pada mata pelajaran IPS.

$H_{a}=$ Model pembelajaran Think Talk Write berbantu media puzzle efektif dalam meningkatkan hasil belajar siswa kelas V pada mata pelajaran IPS.

Dengan kriteria keefektifan dari mdel Think Talk Write, sebagai berikut:

1) Hasil belajar siswa mencapa nilai KKM yaitu $\geq 75$ dengan minimal $75 \%$ dari jumlah seluruh siswa tuntas KKM setelah diberi perlakuan.

2) Adanya perbedaan antara hasil belajar kelas eksperimen dengan kelas kontrol setelah diberi perlakuan dengan model pembelajaran tertentu.

3) Peningkatan nilai posttest yang signifikan dari nilai pretest.

Hasil penelitian pada kelas eksperimen dan kelas kontrol diperoleh nilai akhir (posttest) dengan rata-rata kelas eksperimen 80,32 dan rata-rata kelas kontrol 70,35. Simapangan gabungan 9,8319 sehingga diperoleh thitung sebesar 2,7628 dan tabel sebesar 1,68 dengan $\mathrm{dk}=43$ dengan taraf signifikan 5\%. Karena thitung $>$ tabel yakni 2,7628 > 1,68 maka Ho ditolak dan Ha diterima, dapat disimpulkan bahwa Model pembelajaran Think Talk Write berbantu media puzzle efektif dalam meningkatkan hasil belajar siswa kelas V pada mata pelajaran IPS.

Selanjutnya untuk mengetahui peningkatan nilai posttest pada masing-masing kelas, dilakukan pengujian uji $\mathrm{N}$-gain, dengan rumus $\mathrm{g}=\frac{\mathrm{T}_{2}-\mathrm{T}_{1}}{\mathrm{~T}_{\text {maks }}-\mathrm{T}_{1}}$, dan didapat hasil uji $\mathrm{N}$-gain untuk kelas eksperimen sebesar 0,5085 terletak pada kriteria sedang, hasil perhitungan uji $\mathrm{N}$-gain pada kelas kontrol diperoleh hasil sebesar 0,38558 pada kriteria sedang. Dapat ditarik kesimpulan bahwa hasil uji N-gain kelas eksperimen lebih besar dari pada kelas kontrol dengan selisih nilai sebesar 0,1229.

Peningkatan hasil belajar pada kelas eksperimen yang diberi perlakuan berupa model pembelajaran Think Talk Write dibanding dengan kelas kontrol dengan perlakuan model konvensional, hal ini sesuai dengan pendapat Hamdayama (2014: 221-222) Think Talk Write memiliki beberapa manfaat dalam pembelajaran, yaitu:

1) Model pembelajaran berbasis komunikasi dengan strategi TTW dapat membantu siswa dalam mengkonstruksi pengetahuannya sendiri sehingga pemahaman konsep siswa menjadilebih baik, siswa dapatmengkomunikasikan atau mendiskusikan pemikirannya dengan temannya sehingga siswa saling membantu dan sling bertukar pikiran. Hal ini dapat membantu siswa dalam memahami materi yang diajarkan.

2) Model pembelajaran berbasis komunikasi dengan strategi TTW dapat melatih untuk menuliskan hasil diskusinya kebentuk tulisan secara sistamatis sehingga siswa akan lebih memahami materi dan membantu siswa untuk mengkomunikasikan ide-idenya dalam bentuk tulisan. 


\section{Simpulan dan Saran}

\section{Simpulan}

Berdasarkan hasil penelitian eksperimen yang telah dilaksanakan dapat disimpulkan bahwa model pembelajaran Think Talk Write berbantu puzzle efektif dalam meningkatkan hasil pembelajaran siswa kelas V pada mata pelajaran IPS SD Negeri Kutosari 02 Batang. Keefektifan model pembelajaran Think Talk Write berbantu puzzle terlihat dari:

1) peningkatan hasil belajar (posttest), persentase ketuntasan klasikal untuk kelas VA (kelas eksperimen) $86,63 \%$ dengan nilai rata-rata 80,32. Sedangkan persentase pada kelas VB (kelas control) yaitu $52,174 \%$ dan nilai rata-rata 70,35

2) Hasil Uji t-test diperoleh nilai thitung lebih besar dibanding nilai tabel yaitu 2,76258 > 1,68 sehingga Ha yaitu model pembelajaran Think Talk Write berbantu media Puzzle efektif meningkatkan hasil belajar siswa kelas V mata pelajaran IPS dibanding dengan model ceramah atau konvensional

3) Berdasarkan uji N-gain diperoleh peningkatan hasil belajar kelas Eksperimen (VA) sebesar 0,5085 lebih besar dari pada kelas kontrol (VB) yaitu 0,3856, dengan selisih kelas eksperimen 0,1229 lebih besar dari pada kelas kontrol.

\section{Saran}

Berdasarkan hasil penelitian dan simpulan tersebut, dapat dikatakan bahwa tujuan penelitian dalam penelitian ini telah tercapai. Oleh karena itu disarankan kepada guru-guru hendaknya dapat menjadikan model pembelajaran Think Talk adan Write berbantuan media puzzle model pembelajaran yang harus diterapkan dalam pembelajaran. Tidak hanya model tersebut, namun model-model pembelajaran lainnya juga lebih ditingkatkan lagi agar kegiatan pembelajaran lebih inovatif dan tidak berkesan membosankan bagi peserta didik. Penelitian ini juga dapat dijadikan refrensi untuk melakukan penelitian lebih lanjut dengan materi atau pokok bahasan yang berbeda, tingkatan kelas yang berbeda, dan tambahan variabel baru sebagai kreativitas baru.

\section{Daftar Pustaka}

Aunurrahman. 2009. Belajar dan Pembelajaran. Bandung: Alfabeta.

Chandra, Sari Rahma, Ahmad Fauzan, dan Helma. 2014. Pengaruh Model Pembelajaran Tipe Think Talk Write Dan Gender Terhadap Kemampuan Komunikasi Matematis Siswa Kelas VIII SMPN 12 Padang. Jurnal Pendidikan Matematika Vol. 3 No. 1 (2014): Part 2 Hal 35-40

Departemen Pendidikan Nasional Pusat Bahasa. 2008. Kamus Bahasa Indonesia. Jakarta: Pusat Bahasa.

Gunawan, I Wayan, I Ketut Dibia, Luh Putu Putrini Mahadewi. 2016. Penerapan Model Think Talk Write Untuk Meningkatkan Kemampuan Berpikir Kritis Dan Hasil Belajar Ipa. e-Journal PGSD Universitas Pendidikan Ganesha Jurusan PGSD Vol: 4 No: 1

Hamdayama, Jumanta. 2014. Model dan Metode Pembelajaran Kreatif dan Berkarakter. Bogor: Ghalia Indonesia.

Juniasih, Ni Wyn., I Nym. Jampel, Ni Md. Setuti. 2013. Pengaruh Model Pembelajaran Think Talk Write (Ttw) Berbantuan Media Konkret Terhadap Hasil Belajar Ipa Siswa Kelas IV SD. Mimbar PGSD Vol 1, No 1.

Kustandi, Cecep, Bambang Sutjipto. 2011. Media Pembelajaran Manual dan Digital. Bogor: Ghalia Indonesia.

Lestari, Ni Putu Candra, Gd. Sedanayasa, Desak Pt. Parmiti. 2016. Pengaruh Model Pembelajaran Think Talk Write Berbantuan Media Grafis Terhadap Hasil Belajar Ipa Sekolah Dasar. e-Journal PGSD Universitas Pendidikan Ganesha Jurusan PGSD Vol: 4 No: 1.

Sadiman, Arief s, Rahardjo, dkk. 2012. Media Pendidikan: Pengertian, Pengembangan, dan Pemanfaatannya. Jakarta: PT. RajaGrafindo Persada.

Soegeng, A. Y. 2016. Dasar-Dasar Penelitian. Semarang: Magnum Pustaka Utama.

Suprijono, Agus. 2014. Cooperative Learning Teori dan Aplikasi PAIKEM. Yogyakarta: Pustaka Pelajar 
Susanto, Ahmad. 2013. Teori Belajar Pembelajaran di Sekolah Dasar. Jakarta: Prenadamedia Group.

Undang-Undang Republik Indonesia No. 20 Tahun 2003 tentang Sistem Pendidikan Nasional. Jakarta: Kemendiknas

Uno, Hamzah dan Nurdin Mohamad. 2015. Belajar dengan Pendekatan PAILKEM. Jakarta: PT. Bumi Aksara.

Sari, Komang, dkk. 2015. "Pengaruh Strategi Pembelajaran Think Talk Write (TTW) Terhadap Hasil Belajar Ilmu Pengetehuan Alam Siswa Kelas IV SD N 1 Peguyangan Denpasar". Jurnal PGSD Universitas Pendidikan Ganesha Vol. 3 No. 1 Tahun 2015. (diunduh 14 Desember 2016 pukul 23: 43.

Sugiantari, Gusti Ayu Putu, Gede Sedanayasa, I Wayan Widiana. 2016. Pengaruh Model Pembelajaran Think Talk Write Berbantuan Media Benda Konkret Terhadap Hasil Belajar Matematika Siswa. e-Journal PGSD Universitas Pendidikan Ganesha Jurusan PGSD Vol: 4 No: 1. 